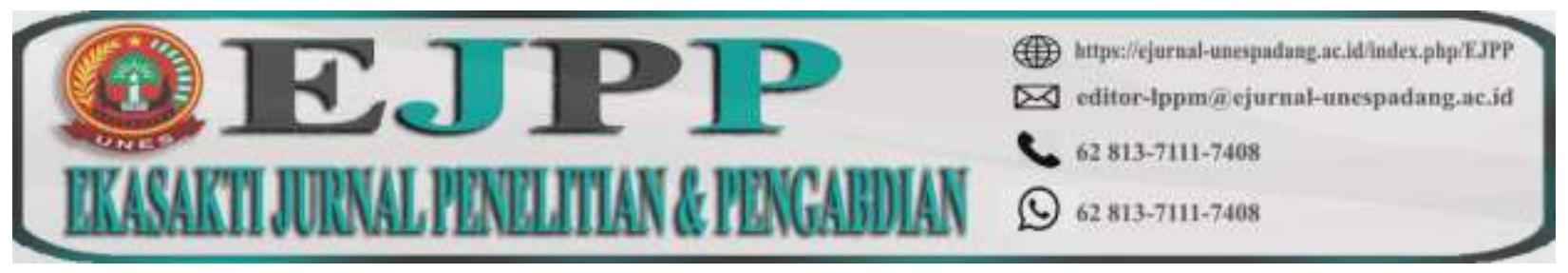

DOI: https://doi.org/10.31933/ejpp.v1i1.229

Received: 05/11/2020, Revised: 20/11/2020, Publish: 22/11/2020

\title{
PENGARUH MOTIVASI KERJA TERHADAP KINERJA PEGAWAI PADA DINAS KEPENDUDUKAN DAN PENCATATAN SIPIL KABUPATEN KERINCI
}

\author{
Riswanto Bakhtiar ${ }^{1}$ \\ ${ }^{1)}$ Prodi Administrasi Publik, Universitas Ekasakti \\ Email: aris.pkbkrc@gmail.com
}

\begin{abstract}
ABSTRAK
Penelitian ini bertujuan untuk mengungkap Pengaruh Motivasi Kerja terhadap Kinerja pegawai pada Dinas Kependudukan dan Pencatatan Sipil Kabupaten Kerinci. Penelitian ini menggunakan metode kuantitatif, dengan variabel eksogen yaitu variabel Motivasi kerja Kinerja pegawai pada Dinas Kependudukan dan Pencatatan Sipil Kabupaten Kerinci. Teknik pengumpulan data dalam penelitian ini menggunakan teknik propotional stratified random sampling. Populasi penelitian ini adalah seluruh pegawai yang ada pada Dinas Kependudukan dan Pencatatan Sipil Kabupaten Kerinci. Responden dalam penelitian ini berjumlah 96 sampel. Teknik analisis data yang digunakan adalah path analysis dan dibagi menjadi 2 jalur yaitu sub strukur 1 dan Sub Struktur 2, Data dikumpulkan melalui angket yang telah di uji validitas dan reliabilitasnya terlebih dahulu baik konten maupun uji empirik item di lapangan. Hasil penelitian ini telah menemukan bahwa model hipotesis, terbukti dapat di jadikan sebuah model baru dalam meningkatkan kinerja pegawai pada Dinas Kependudukan dan Pencatatan Sipil Kabupaten Kerinci. Temuan pada penelitian menunjukan ini bahwa: Terdapat pengaruh Motivasi kerja terhadap kinerja.
\end{abstract}

Kata Kunci: Motivasi Kerja, Kinerja Pegawai, Dinas Kependudukan dan Pencatatan Sipil, Kabupaten Kerinci.

\begin{abstract}
This study aims to reveal the effect of work motivation on employee performance at the Department of Population and Civil Registration of Kerinci Regency. This study uses quantitative methods, with exogenous variables, namely the work motivation variable, employee performance at the Department of Population and Civil Registration, Kerinci Regency. The data collection technique in this study used a proportional stratified random sampling technique. The population of this study were all employees at the Department of Population and Civil Registration of Kerinci Regency. Respondents in this study amounted to
\end{abstract}


96 samples. The data analysis technique used is path analysis and is divided into 2 paths, namely sub-structure 1 and sub-structure 2. Data is collected through a questionnaire that has been tested for its validity and reliability in advance both in terms of content and empirical test of items in the field. The results of this study have found that the hypothetical model is proven to be used as a new model in improving the performance of employees at the Department of Population and Civil Registration of Kerinci Regency. The findings in this study indicate that: There is an effect of work motivation on performance.

Keywords: Work Motivation, Employee Performance, Department of Population and Civil Registration, Kerinci Regency.

\section{PENDAHULUAN}

Pelayanan publik sebagaimana diatur dalam Undang-Undang Nomor 25 tahun 2009 Tentang Pelayanan Publik dalam Pasal (1) Ayat (1) merupakan kegiatan dalam rangka pemenuhan kebutuhan pelayanan sesuai dengan peraturan perundang-undangan bagi setiap warga negara dan penduduk atas barang, jasa dan atau pelayanan administratif yang disediakan oleh penyelenggara publik. Kemudian dipertegas lagi dalam Pasal (7) standar pelayanan adalah tolak ukur yang dipergunakan sebagai pedoman sebagai pedoman penyelenggaraan pelayanan dan acuan penilaian kualitas pelayanan sebagai kewajiban dan janji penyelenggara publik kepada masyarakat dalam rangka pelayanan yang berkualitas, cepat, mudah terjangkau dan terukur.

Uraian undang-undang tersebut diatas memberikan penegasan bahwa pemerintah berkewajiban memberikan pelayanan dengan sebaik-baiknya kepada masyarakat sebagai penerima pelayanan, sesuai dengan kebutuhan masyarakat. Pelayanan yang harus diberikan adalah pelayanan yang baik, mudah, murah, cepat dan terukur. Untuk memberikan pelayanan tersebut harus berdasarkan atas tugas pokok dan fungsi Aparatur Sipil Negara yang tercantum dalam Undang Undang Nomor 5 Tahun 2014 tentang Aparatur Sipil Negara yang bertugas sebagai pelaksana kebijakan publik, pelayan publik, serta sebagai perekat dan pemersatu bangsa, Namun pada kenyataannya pelayanan publik menampilkan wajah buruk dimata masyarakat.

Hal ini disampaikan oleh Sekretaris Dinas Kependudukan dan Pencatatan Sipil Kabupaten Kerinci Bapak Nafritman, S.E.,M.Si, bahwa wajah buruk yang diperlihatkan Pegawai Negeri Sipil atau disebut juga Aparatur Sipil Negara terlihat dari pelayanan kepada masyarakat yang tidak maksimal, bersikap pasif terhadap pekerjaan, tidak tepat waktu dalam menyelesaikan pekerjaannya. Ini jelas terlihat sebagai bentuk rendahnya motivasi kerja pegawai negeri sipil dalam menjalankan tugas pokok dan fungsinya sebagai aparatur negara. Keterlambatan masuk kerja, dan masih ada sebagian pegawai yang meninggalkan tugas pada jam kerja tanpa keterangan yang jelas, bahkan seringkali ada Pegawai Negeri Sipil yang tidak masuk kantor dengan berbagai alasan, sehingga pekerjaannya sebagai pelayan publik tidak berjalan dengan baik. 
Pelayanan publik yang kinerja pegawainya dikaitkan dengan kepemimpinan, motivasi kerja, kompensasi dan disiplin kerja menjadi perhatian para peneliti di bidang sumber daya manusia saat ini, sebagai contoh adalah pelayanan publik pada Dinas Kependudukan dan Pencatatan Sipil Kabupaten Kerinci. Dinas Kependudukan dan Pencatatan Sipil Kabupaten Kerinci merupakan organisasi perangkat daerah yang menjadi ujung tombak pemerintah daerah melakukan atau memberikan pelayanan terhadap masyarakat. Terutama pelayanan administrasi kependudukan sangat diperlukan adanya sumber daya manusia yang handal untuk dapat melakukan perencanaan, penatausahaan, pelaksanaan dan melakukan pengawasan. Tanpa dukungan kualitas sumber daya manusia yang terlibat didalamnya, maka peran pimpinan terhadap bawahan akan mempengaruhi berhasil tidaknya suatu tujuan organisasi. Oleh karena itu Pemimpin merupakan tokoh yang dapat menaikkan kinerja bawahannya.

Dalam rangka mewujudkan tercapainya tujuan organisasi tidak hanya tergantung pada peralatan modern, sarana dan prasarana yang lengkap, tetapi justru lebih tergantung pada manusia yang melaksanakan pekerjaan tersebut. Keberhasilan suatu organisasi sangat dipengaruhi oleh kinerja individu pegawainya. Kinerja pegawai bukanlah suatu kebetulan saja, tetapi banyak faktor yang mempengaruhi diantaranya pemberian motivasi.

Dalam keterangan lain Sekretaris Dinas Kependudukan dan Pencatatan Sipil Kabupaten Kerinci Bapak Nafritman, S.E.,M.Si menambahkan bahwa para pegawai akan lebih termotivasi untuk melakukan tanggung jawab atas pekerjaan mereka apabila organisasi atau perusahaan mengerti dan memperhatikan betul akan kebutuhan para karyawan, yang pada dasarnya adalah mereka bekerja untuk mendapatkan kompensasi, dalam hal ini berbentuk gaji, tunjangan, insentif ataupun remunerasi, pelatihan dan cuti sementara kompensasi seperti itu yang tidak didapatkan oleh pegawai Dinas Kependudukan dan Pencatatan Sipil Kabupaten Kerinci, selain gaji, tunjangan yang sudah merupakan hak mereka sesuai dengan pangkat, jabatan dan golongan.

Mengingat kedudukan dan peranan pegawai negeri sipil berdasarkan Pancasila dan Undang-Undang Dasar 1945 adalah sebagai aparatur negara, maka aparatur sipil negara dituntut untuk bekerja secara profesional, disiplin, jujur dan bertanggung jawab. Seorang pegawai negeri harus mampu memposisikan dirinya sebagai aparatur negara. Pegawai negeri hendaknya memiliki motivasi kerja.

Menurut Sekretaris Dinas Kependudukan dan Pencatatan Sipil, terhitung 2 tahun terakhir pegawai Dinas Kependudukan dan Pencatatan Sipil Kabupaten Kerinci tidak ada lagi anggaran untuk meningkatkan kinerja pegawai seperti Tunjangan Kinerja Daerah (TKD), Tunjangan Beban Kerja ataupun insentif serta remunerasi yang akan menjadi motivasi pegawai untuk lebih meningkat disiplin dan kinerjanya. Sementara dengan kondisi seperti itu pegawai kita dituntut untuk tetap berkerja dengan optimal dalam memberikan pelayanan.

Motivasi kerja pegawai Dinas Kependudukan dan Pencatatan Sipil Kabupaten Kerinci sangat diperlukan, karena motivasi kerja merupakan kekuatan yang mendorong seorang pegawai untuk mau mengasah keterampilannya dalam bekerja dan melakukan tugas yang menjadi kewajibannya dengan penuh tanggung jawab dan keikhlasan demi mencapai sebuah tujuan yang diinginkan ataupun sasaran yang telah ditetapkan oleh organisasi. 
Motivasi dan kinerja memiliki hubungan antara satu dengan lainnya. Kinerja merupakan fungsi dari interaksi antara kemampuan dan motivasi (Robbins, 2003: 233). Sedangkan Menurut Kreitner dan Anglo Kinicki (2001:205) motivasi kerja dapat dipastikan mempengaruhi kinerja, walaupun bukan satu-satunya faktor yang membentuk kinerja.

Motivasi seseorang berawal dari kebutuhan, keinginan dan dorongan untuk bertindak demi tercapainya kebutuhan atau tujuan. Hal ini menandakan seberapa kuat dorongan, usaha, intensitas dan kesediaannya untuk berkorban demi tercapainya tujuan. Semakin kuat dorongan atau motivasi akan semakin tinggi tingkat kinerjanya. Mathis $(2002 ; 114)$ mengatakan motivasi merupakan keinginan dalam diri seseorang yang menyebabkan orang tersebut bertindak. Biasanya orang bertindak karena suatu alasan untuk mencapai tujuan. Memahami motivasi sangatlah penting, reaksi terhadap kompensasi dan persoalan sumber daya manusia yang lain dipengaruhi dan mempengaruhi motivasi.

Motivasi kerja merupakan dorongan yang timbul dari diri seseorang untuk bertindak, berbuat atau melakukan sesuatu dalam pemenuhan kebutuhannya. Jika motivasi kerja seseorang untuk mencapai sesuatu tujuan semakin tinggi maka semakin tinggi pula usaha yang dilakukan untuk mencapai tujuan tersebut. Begitu juga sebaliknya, semakin sering seseorang gagal melakukan sesuatu mencapai tujuan, maka kemungkinan menipis motivasinya. Motivasi kerja merupakan penggerak utama yang bersumber dari dalam atau diluar diri seseorang yang mendorong untuk berbuat dan memperlihatkan tingkat kinerja dan produktivitas sesuai dengan standar yang dipahami dan berlaku dalam pekerjaan.

Ada berbagai macam teori tentang motivasi dalam berbagai disiplin ilmu, secara umum teori-teori tersebut diantaranya teori Mc Celland banyak digunakan dalam menilai kinerja pegawai, Mc Celland memperkenalkan bahwa terdapat tiga jenis motivasi, yaitu:

Kebutuhan berprestasi ( $N-A c h)$

Need for achievement merupakan kebutuhan seorang pegawai untuk berprestasi yang mana kebutuhan tersebut merupakan refleksi dari dorongan akan rasa tanggung jawab dan keinginan pegawai untuk memecahkan masalah. Pegawai yang memiliki keinginan untuk berprestasi cenderung suka menghadapi tantangan baru untuk meningkatkan kualitas diri dan pekerjaannya, senang mengambil resiko, dan ingin selalu mendapatkan feedback atas pekerjaannya baik berupa pujian ataupun gaji/upah.

1. Kebutuhan kekuasaan (N-Power)

Need for power atau kebutuhan akan kekuasaan merupakan refleksi dari dorongan seorang pegawai untuk mencapai autoritas dan memiliki pengaruh kepada orang lain. Keinginan akan kekuasaan dari seorang pegawai merupakan kebutuhannya dimana orang lain akan berperilaku sesuai dengan keinginannya tanpa dipaksa, dengan arti kata lain pegawai tersebut ingin untuk dapat mengendalikan dan mempengaruhi orang lain. Pegawai yang memiliki keinginan akan kekuasaan cenderung ingin menduduki jabatan/posisi tertentu, ingin mengontrol dan mempengaruhi orang lain, senang berkompetisi, dan ingin mendapatkan status dan pengakuan baik dari rekan kerja ataupun atasan. 
2. Berkeinginan berafiliasai (Need-Affil)

Need for affiliation merupakan kebutuhan seorang pegawai untuk berafiliasi, berinteraksi dengan orang lain, berada bersama orang lain, dan tidak melakukan sesuatu yang akan merugikan orang lain. Kebutuhan pegawai akan afiliasi merupakan dorongan untuk memiliki hubungan personal yang ramah dan akrab. Ketika seorang pegawai memiliki keinginan untuk berafiliasi, pegawai tersebut akan berusaha melakukan sesuatu sesuai dengan apa yang disukai orang lain untuk menjaga hubungannya dengan orang lain. Pegawai yang memiliki keinginan berafiliasi yang tinggi cenderung untuk berada dalam satu kelompok, ingin disukai oleh rekan kerjanya, dan mau melakukan sesuatu untuk tetap berada dalam kelompok tersebut.

Teori yang menjelaskan tentang motivasi diatas dapat disimpulkan teori tersebut memberikan penjelasan bahwa motivasi kerja seseorang dapat berasal dari dalam dirinya (faktor intrinsik) dan dari luar dirinya (ekstrinsik). Desakan untuk memenuhi kebutuhan dasar manusia, keinginan untuk maju, mendapatkan pengakuan, dan berprestasi merupakan dorongan yang berasal dari dalam diri pegawai. Sedangkan keinginan untuk mendapatkan upah, membangun relasi, mandapatkan status dan mendapatkan tanggung jawab merupakan dorongan yang berasal dari luar diri seorang pegawai. Motivasi kerja diatas tidak hanya menjadi pendorong bagi pegawai untuk bekerja, tetapi pegawai juga akan membandingkan apa yang telah diberikannya kepada organisasi tempat ia bekerja dengan apa yang di terima sebagai bentuk keadilan yang didapat di tempat kerjanya.

Seorang individu yang mempunyai motivasi berprestasi didalam suatu perusahaan atau organisasi, mempunyai hubungan yang sangat penting karena individu yang berhasil adalah individu-individu yang dapat menyelesaikan sesuatu, mereka adalah pegawai yang dapat memecahkan masalah-masalah dan mencapai tujuan organisasi. Dalam praktek mereka adalah individu-individu yang mengerjakan dan mencapai hasil yang diinginkan. Menurut Mc.Clelland, individu yang sungguh-sungguh mencapai motivasi berprestasi memiliki sifat-sifat sebagai berikut:

a. Mereka lebih menyukai menyerang dan memecahkan sendiri masalah-masalah. Mereka mengembangkan perasaan memiliki tugas yang dihadapi dan meskipun mereka dapat bekerja dengan orang lain, mereka lebih menyukai situasi-situasi dimana mereka menganggap satu-satunya tanggung jawab adalah pemecahan masalah atau penyelesaian tugas.

b. Orang-orang yang sungguh-sungguh mencapai motivasi cenderung menuju ke situasisituasi tersebut, dimana mereka dengan segera dapat memperoleh umpan balik pada hasil kerja mereka. Inilah sebabnya mengapa Mc.Clelland mengatakan sangat banyak orang yang berhasil terdapat dalam pekerjaan, dimana orang tersebut mengetahui dengan segera apabila ia mencapai hasil yang diinginkan. Orang yang berhasil adalah orang yang mengetahui secara terus-menerus betapa baik dia bekerja dan menginginkan suatu umpan balik demikian untuk menjadi kenyataan dan kejujuran. 
c. Orang yang berhasil adalah juga orang yang menentukan dengan sebanyak-banyaknya tujuan yang mengandung risiko, sehingga dia dapat menambah sebesar-besarnya kesempatan untuk mendapatkan kepuasan hasil pekerjaan.

Dengan uraian tersebut dapat disimpulkan seorang pegawai atau pekerja akan melaksanakan pekerjaaannya dengan baik apabila mereka memiliki motivasi kerja yang jelas jelas. Motivasi pegawai untuk bekerja apakah hanya untuk bekerja, atau mereka bekerja untuk meningkatkan status sosial, atau mereka bekerja untuk mendapatkan sesuatu guna memenuhi kebutuhan mereka. Disini sangat jelas bahwa kinerja pegawai sangat dipengaruhi oleh motivasi kerja.

Selain dari teori Mc Celland, teori Dua Faktor Herzberg juga merupakan teori motivasi kerja, beberapa ahli menyebut teori dua faktor Herzberg ini dengan sebutan motivation-hygiene theory dan telah mendapatkan pengakuan yang luas dalam lingkup manajemen dan berdampak dalam mendesain pekerjaan (Thomas, 2011:427). Teori Herzberg ini mengkategorikan 2 (dua) kelompok kategori atau faktor, yaitu: (1) Faktor motivator, yaitu faktor-faktor yang mendorong seseorang untuk berprestasi dan berasal dari dalam dirinya sendiri. Bagian yang termasuk dalam faktor motivator yaitu pekerjaan, adanya pengakuan dari orang lain atas sebuah pencapaian, adanya tanggung jawab untuk bekerja, kesempatan untuk melakukan sesuatu yang bermanfaat, kesempatan untuk terlibat dalam proses pengambilan keputusan, adanya perasaan diperlukan oleh organisasi. (2) Faktor pemeliharaan atau faktor hygiene, faktor pemeliharaan merupakan faktor yang bersifat ekstrinsik dan berasal dari luar diri seseorang yang juga turut menentukan perilaku seseorang dalam hidup. Faktor ini mencakup status dan hubungan pegawai dalam organisasi, supervisi dari atasan, kebijakan dalam organisasi, kondisi kerja, dan system imbalan yang berlaku.

\section{METODE PENELITIAN}

Metode yang digunakan pada penelitian ini adalah metode kuantitatif. Variabel terikat yang digunakan adalah kinerja sedangkan variabel bebas adalah disiplin kerja, kepuasan kerja. Dalam penelitian ini definisi operasional variabel adalah sebagai berikut:

1. Variabel Kinerja (Y). Kinerja merupakan merupakan gambaran mengenai tingkat pencapaian pelaksanaan suatu program kegiatan atau kebijakan dalam mewujudkan sasaran, tujuan visi dan misi organisasi yang di tuangkan melalui perencanaan strategi suatu organisasi. Indikator (a) Kualitas pekerjaan, (b) Kuantitas, (c) Efektifitas waktu kerja, (d) Sikap dan tanggung jawab, (e) Kerjasama dan keandalan, (f) Kejujuran.

2. Variabel Motivasi Kerja (X1), Motivasi kerja merupakan sebuah dorongan yang timbul dari dalam diri seseorang untuk berbuat sesuatu dan menuntun cara bersikap seseorang atas sebuah pekerjaan atau perbuatan. Indikator (a) daya pendorong dan keinginan bertindak untuk mencapai tujuan. (b) mengarahkan daya dan potensi yang ada untuk meraih keberhasilan, (c) mengerjakan tugas sesuai dengan keterampilan dan kemampuan, (d) tanggung Jawab mengerjakan sesuatu dengan sebaik-baiknya, (e) 
keinginan bekerja sama secara produktif, (f) Pengakuan dan penghargan atas usaha yang dilakukan.

Adapun populasi dari penelitian ini adalah Seluruh Pegawai pada Dinas Kependudukan dan Pencatatan Sipil Kabupaten Kerinci yang berjumlah 125 Orang. Untuk penentuan sampel dalam penelitian ini menggunakan teknik propotional stratified random sampling yaitu teknik pengambilan sampel yang diambil dari masing-masing sub populasi yang diambil secara acak berdasarkan proporsi usia pegawai yang ada pada setiap sub populasi pada Dinas Kependudukan dan Pencatatan Sipil Kabupaten Kerinci. Berdasarkan perhitugan untuk mendapatkan sampel dengan menggunakan rumus slovin maka didapatkan sampel yang akan digunakan sebanyak 96.

Jenis data yang dikumpulkan dalam penelitian ini diambil dari dua sumber yaitu data primer dan data sekunder. Data primer dalam penelitian ini akan penulis dapatkan melalui angket yang diberikan kepada pegawai. Sedangkan data sekunder digunakan untuk mendukung data primer yang akan berasal dari website, jurnal online, studi pustaka dan referensi terkait dengan penelitian.

\section{HASIL DAN PEMBAHASAN}

\section{Pengaruh Motivasi Kerja terhadap Kinerja Pegawai}

Setelah di dapatkan hasil penelitian dan dilakukan uji persamaan regresi, maka peneliti mencoba memaparkan pembahasan temuan hasil penelitian tersebut. Adapun pembahasan yang terdapat pada temuan penelitian ini adalah sebagai berikut.

Tabel 1. Analisis Varians Linearitas Motivasi Kerja terhadap Kinerja

\begin{tabular}{|c|c|c|c|c|c|c|c|}
\hline \multicolumn{8}{|c|}{ ANOVA Table } \\
\hline & & & $\begin{array}{l}\text { Sum of } \\
\text { Squares }\end{array}$ & df & $\begin{array}{l}\text { Mean } \\
\text { Square }\end{array}$ & $\mathrm{F}$ & Sig. \\
\hline \multirow{5}{*}{$\begin{array}{l}\text { KINERJAPEGAWAI * } \\
\text { MOTIVASIKERJA }\end{array}$} & Between & (Combined) & 231.496 & 14 & 16.535 & 2.859 & .002 \\
\hline & Groups & Linearity & 111.662 & 1 & 111.662 & 19.307 & .000 \\
\hline & & $\begin{array}{l}\text { Deviation from } \\
\text { Linearity }\end{array}$ & 119.835 & 13 & 9.218 & 1.594 & .104 \\
\hline & Within $\mathrm{G}$ & & 468.462 & 81 & 5.783 & & \\
\hline & Total & & 699.958 & 95 & & & \\
\hline
\end{tabular}

Sumber: Data Olahan, 2020

Berdasarkan hasil analisis data pada tabel di atas dapat dilihat bahwa nilai $\mathrm{F}$ hitung dan nilai sign (deviation from linierity), lebih besar dari pada Alpha, karena nilai signifikansi lebih besar dari pada Alpha maka dapat dinyatakan bahwa variabel Motivasi kerja dan kinerja Pegawai linear.

Berdasarkan hasil penelitian pada Dinas Kependudukan Dan Pencatatan Sipil menunjukan bahwa motivasi kerja berpengaruh langsung terhadap kinerja pegawai. Hal ini sesuai dengan teori yang dinyatakan oleh Robbins, (2003: 233), Kreitner dan Anglo Kinicki (2001:205), Mathis (2002; 114) yang menyatakan bahwa Motivasi dan kinerja memiliki hubungan antara satu dengan lainnya. Kinerja merupakan fungsi dari interaksi antara kemampuan dan motivasi, hal yang senada juga diungkapkan oleh motivasi kerja dapat dipastikan mempengaruhi kinerja, walaupun bukan satu-satunya faktor yang membentuk kinerja. Sebagaimana hasil penelitian 
Elpis Anto Manalu (2016), Yuli Suwati (2013:41-55), Agung Setiawan (2013:1245-1253) Berdasarkan hasil penelitian dan teori-teori yang diungkapkan oleh para ahli, yang menyatakan variabel motivasi kerja secara bersama-sama dengan variabel lain memiliki pengaruh yang signifikan dengan kinerja pegawai. Artiny semakin baik motivasi kerja maka akan dapat meningkatkan kinerja pegawai, sebaliknya jika motivasi kerja rendah maka akan semakin rendah pula kinerja pada pegawai.

\section{KESIMPULAN}

Berdasarkan hasil uji hipotesis untuk mengetahui pengaruh motivasi kerja terhadap kinerja pegawai pada Dinas Kependudukan dan Pencatatan Sipil, maka dapat ditarik kesimpulan bahwa: Terdapat pengaruh langsung motivasi kerja kerja terhadap kinerja pegawai pada Dinas Kependudukan dan Pencatatan Sipil Kabupaten Kerinci. artinya ada pengaruh yang signifikan positif variabel motivasi kerja terhadap kinerja pegawai.

\section{REFERENSI}

Robbins, P. Stephen. (2003). Perilaku Organisasi. Edisi Sembilan, Jilid 2. Edisi Bahasa Indonesia. Jakarta: PT Indeks Kelompok Gramedia.

Kreitner, Robert and Angelo Kinicki, 2001. Organizational Behavior. Fifth Edition. Irwin McGraw-Hill.

Mathis Robert, Jackson John. 2002. Manajemen Sumber Daya Manusia. Jakarta: Salemba empat.

Thomas H.Stone 2011. Manajemen Sumber Daya Manusia Dalam Organisasi Publik dan Bisnis.Edisi kedua. Jakarta: Penerbit Alfabeta 